valproate binds to a macromolecule, producing an immunogenic structure. The antibody is directed against platelets because of their membrane fatty acids, which are chemically and configuratively similar to those of valproate.

We suggest that all patients whose valproate assay exceeds the recommended concentration have regular platelet counts performed.

${ }^{1}$ Richardson, S G N, Fletcher, D J, and Jeavons, P M, Clinical and Pharmacological Aspects of Sodium Valproate (Epilim) in the Treatment of Epilepsy. MCS Consultants, England, 1975.

2 von Voss, H, et al, British Medical fournal, 1976, 1, 179.

3 Winfield, D A, et al, British Medical fournal, 1976, 2, 981.

4 Columbani, J, et al, paper presented at Fourth International Histocompatibility Workshop, Los Angeles, 1970.

5 Karpatkin, S, et al, Clinical Immunology and Immunopathology, 1973, 2, 1.

(Accepted 13 October 1978)

Department of Haematology, John Bonnett Clinical Laboratories, Addenbrooke's Hospital, Cambridge CB2 2QQ

R M SANDLER, MRCP, senior registrar

Ida Darwin Hospital, Cambridge CR1 5EE

C EMBERSON, LRCP \& SI, registrar

Addenbrooke's and Ida Darwin Hospitals, Cambridge

G E ROBERTS, MA, MRCPSYCH, consultant psychiatrist

East Anglia Regional Blood Transfusion Centre, Cambridge CB2 2PT

D VOAK, PHD, MRCPATH, principal scientific officer

J DARNBOROUGH, MB, FRCPATH, director

Department of Clinical Chemistry, Peterborough District Hospital, Peterborough PE3 6DA

A F HEELEY, PHD, MRIC, principal scientific officer

\section{Response to penicillamine of lead concentrations in CSF and blood in patients with motor neurone disease}

Recent reports of high concentrations of lead in the CSF and plasma of patients with motor neurone disease $(\mathrm{MND})^{12}$ have again suggested a possible relationship between MND and lead toxicity. If this is so it is important to establish the efficacy of treatment with a chelating agent. This study reports the CSF and whole blood lead concentrations in patients with MND and controls and an uncontrolled pilot study of penicillamine treatment of 12 patients with MND.

\section{Patients, methods, and results}

Thirteen patients with an established diagnosis of MND were studied. A further 13 patients with neurological disease without evidence of motor neuropathy were selected as controls. No patient gave a history of occupational risk or prior exposure to lead. CSF and blood samples were collected from all patients into lead-free containers. CSF lead concentration was determined by flameless atomic absorption spectrophotometry and whole blood lead concentration by a standard colorimetric assay using diphizone. Twelve patients with $M N D$ were then given penicillamine up to a maximum dose of $1.5 \mathrm{~g} /$ day for 4-6 months. The response was assessed in terms of subjective wellbeing, functional capacity at home, and clinical examination.

Blood lead concentrations were normal in both groups. None was above $15 \mu \mathrm{g} / 100 \mathrm{ml}(0.75 \mu \mathrm{mol} / 1)$. Mean (. SD) CSF concentrations in patients with MND were $6.7 \pm 7.5 \mu \mathrm{g} / 100 \mathrm{ml}(0.32 \pm 0.36 \mu \mathrm{mol} / \mathrm{l})$ and in controls $5.9 \pm 4 \cdot 2 \mu \mathrm{g} / 100 \mathrm{ml}(0 \cdot 28 \pm 0 \cdot 20 \mu \mathrm{mol} / 1)$. There was no statistical difference between these values using the Student $t$ test (figure). Two patients reported subjective improvement on penicillamine but none showed objective improvement. Two patients died of their disease during the study period and the remaining ten all showed objective evidence of deterioration.

\section{Comment}

It has long been recognised that motor neuropathy due to lead toxicity may mimic MND. Despite a history of significant lead exposure in some patients, ${ }^{3}$ however, studies of those with confirmed

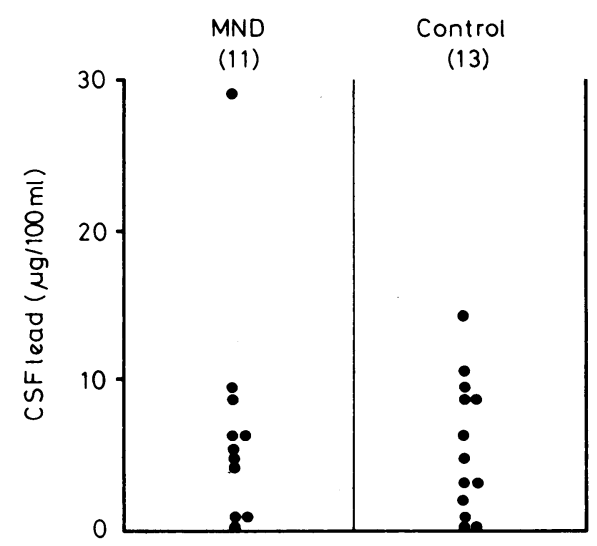

Lead concentrations. SF of controls and MND patients.

MND have failed to find raised lead concentrations in urine, whole blood, or bone. ${ }^{34}$ Recently there have been reports of raised lead concentrations in CSF and plasma but not whole blood of patients with MND. ${ }^{12}$ Our results also show normal blood concentrations, but do not confirm the report of raised CSF concentrations. Whether this arises from differences in methodology or in patient selection is uncertain. Conradi et al, ${ }^{2}$ however, recognised the anomaly in their own results in which the control plasma lead concentrations were considerably lower than their own previously reported concentrations. Previous treatment with chelating agents has been reported, ${ }^{3-5}$ with occasional apparent succees. ${ }^{35}$ Interpretation has been difficult, however, because the improvement was subjective, the duration of treatment brief, or the initial diagnosis open to doubt. Our study was of more patients than in other studies, full lead studies were performed, and treatment continued for 4-6 months. The failure to improve on penicillamine is in keeping with observations with penicillamine, thioctic acid, and EDTA. ${ }^{4}$

Our failure to confirm reports of increased CSF lead concentrations in MND does not exclude the possibility of selective neuronal binding of lead, and necropsy studies of tissue lead and other heavy metal concentrations would be of interest. Neither does the therapeutic failure of penicillamine exclude the possibility of lead toxicity initiating the disease process. It does, however, suggest that continuing exposure to lead is not important in the progression of the disease once established.

1 Conradi, S, Ronnevi, L, and Vesterberg, O, fournal of the Neurological Sciences, 1976, 29, 259.

${ }^{2}$ Conradi, S, Ronnevi, L, and Vesterberg, O, fournal of Neurology, Neurosurgery, and Psychiatry, 1978, 41, 389.

${ }^{3}$ Campbell, A M G, Williams, E R, and Barltrop, D, fournal of Neurology, Neurosurgery, and Psychiatry, 1970, 33, 877.

${ }^{4}$ Currier, R D, and Haerer, A F, Archives of Environmental Health, 1968, 17,712 .

${ }^{5}$ Jusic, A, and Sustarko, M, Lancet, 1977, 2, 1034.

(Accepted 13 October 1978)

Department of Neurology, Dundee Royal Infirmary, Dundee DD1 9ND

A O HOUSE, MRCP, senior house officer in neurology (present appointment: registrar in psychiatry, Mapperley Hospital, Nottingham)

$\mathrm{R}$ J ABBOT'T, MRCP, registrar in neurology

D L W DAVIDSON, MRCP, consultant neurologist

I T FERGUSON, MRCP, registrar in neurology (present appointment: lecturer in neurology, Manchester Royal Infirmary)

J A R LENMAN, FRCPED, consultant neurologist

\section{Correction}

Physiotherapy and intermittent positive-pressure ventilation of chronic bronchitis

We regret that an error occurred in the paper by Drs D A G Newton and $\mathrm{H}$ G Bevans (2 December, $p$ 1525). The conversion factor for $\mathrm{PaO}_{2}$ and $\mathrm{PaCO}_{2}$ at the foot of tables $\mathrm{I}, \mathrm{III}$, and $\mathrm{V}$ and fig 3 should have read $1 \mathrm{kPa} \approx$ $7.5 \mathrm{~mm} \mathrm{Hg}$. 